\title{
Morphological pattern of colonization by mycorrhizal fungi and the microbial activity observed in Barbados cherry crops
}

\author{
José Maria Tupinambá da Silva Júnior ${ }^{*}$ Paulo Furtado Mendes Filho $^{1}$ Vânia Felipe Freire Gomes ${ }^{1}$ \\ Aldênia Mendes Mascena de Almeida ${ }^{1}$ Kaio Gráculo Vieira Garcia ${ }^{1}$
}

'Departamento de Ciências do Solo, Universidade Federal do Ceará (UFC), Av. Mister Hull, 2977, 60440-554, Campus do Pici, Fortaleza, CE, Brasil. E-mail: jmtsilvajunior@gmail.com. "Corresponding author.

\begin{abstract}
Our objective was to evaluate the morphological pattern of colonization by arbuscular mycorrhizal fungi (AMF) as well as to study the microbiological activity of the soil on family farms where Barbados cherry was cultivated. Soil and root samples were selected from four areas in the municipality of Maranguape-CE where Barbados cherry was grown, which were named according to the age of plants in the following manner: A1-3, A2-3, and A3-3 (3 years), and A4-2 (2 years). After sampling, the arbuscular mycorrhizal colonization, morphological colonization pattern, basal soil respiration (SBR), and density of mycorrhizal spores (DS) were analyzed. The Paris-type morphological pattern was predominant in the root system of Barbados cherry; the affinity of this pattern in the culture was clear. Time of installation and management of Barbados cherry orchards in family farming areas promoted reduction in SBR. P levels in the soil may have negatively influenced root colonization and density of mycorrhizal spores.
\end{abstract}

Key words: Malpighia emarginata D.C., family farming, mycorrhizal.

Padrão morfológico de colonização por fungos micorrízicos arbusculares e atividade microbiana em cultivos de acerola

RESUMO: Objetivou-se avaliar o padrão morfológico de colonização por Fungos Micorrízicos Arbusculares (FMA), bem como a atividade microbiológica do solo sob cultivo da aceroleira em áreas de agricultores familiares. Para as coletas de solos e raizes foram selecionadas quatro áreas com aceroleira no município de Maranguape-CE, essas foram denominadas de acordo com a idade das plantas A1-3, A2-3 e A3-3 (3 anos) e A4-2 (2 anos). Após as coletas foi analisado a colonização micorrízica arbuscular, o padrão morfológico de colonização, a respiração basal do solo (RBS) e a densidade de esporos micorrízicos (DE). O padrão morfológico do tipo Paris foi predominante no sistema radicular da aceroleira, ficado claro a afinidade desse padrão na cultura. O tempo de instalação e o manejo do pomar da aceroleira nas áreas de agricultura familiar promoveu uma redução na RBS. Os teores de P no solo podem ter influenciado negativamente a colonização radicular e a densidade de esporos de fungos micorrízicos arbusculares.

Palavras-chave: Malpighia emarginata D.C., agricultura familiar, micorriza.

\section{INTRODUCTION}

Acerola numbers have increased in recent years in Brazil, and the species is grown in virtually all regions of the country. Its fruits are mainly sold fresh and in the form of frozen pulp. The acerola tree is considered as a drought-resistant and rustic plant. Owing to these characteristics, this plant species adapts to conditions of young and low-fertility soils, such as Brazilian Northeast soils (FIGUEIREDO NETO et al., 2014).

The increased demand for fresh acerola and its pulp in the Brazilian Northeast has led to an increase in the number of biotechnological research studies on sustainable soil management, microbiological activity, and the association between acerola trees and arbuscular mycorrhizal fungi (AMF). Soil microorganisms are crucial for soil organic matter cycling (ROSA et al., 2017) and nutrient absorption, and their presence leads to the enhancement of nutrient uptake, microbiological activity, and an increase in acerola production.

These studies aim to develop biotechnological methods for the use of soil microorganisms in both sustainable soil 
management and acerola crop production associated with AMF because this plant is mycotrophic, that is, it requires mycorrhizal association to enhance nutrient absorption, particularly of phosphorus, thereby increasing the plant growth and productivity (BALOTA et al., 2011; BAUM et al., 2015). However, limited number of studies on acerola growth and symbiosis with AMF have been published in the literature thus far, despite its importance. Another relevant fact is the absence of studies regarding the mycorrhizal morphological patterns prevalent in acerola roots, which underlines the importance of the present pioneering study on acerola growth.

This symbiotic association also increases the tolerance of acerola plants to biotic and abiotic environmental stresses during the nursery-to-field transplantation phase. Thus, mycorrhization of acerola seedlings enhances their initial growth in the nursery, allowing increased plant growth and nutrition in the field (FERREIRA et al., 2015). Benefits of acerola-AMF symbiosis are related to the morphological formation of intra- and intercellular endophytic structures. Morphology of these structures in arbuscular mycorrhizae has been classified as "Arum", "Paris", and "intermediary". The "Paris" type has intracellular hyphae, which can be folded; "Arum" is observed in intercellular hyphae and arbuscules; and "intermediary" has both "Arum" and "Paris" structures (DICKSON, 2004).

Thus, advantages for acerola plants resulting from symbiosis with AMF are correlated with the presence of those structures in roots. For example, in the Arum type, the symbionts come into close contact through an interface formed as the arbuscules grow. Nutrients absorbed from the soil, especially $\mathrm{P}$ and photoassimilated carbon, are transferred through this interface, which is considered as an exchange site for symbiosis. Conversely, in the Paris type, intracellular fungal hyphae predominate, spreading from cell to cell within the root cortex and extending to the soil. Those hyphae play a key role in symbiosis because they affect soil nutrient and water absorption by aiding transfer to the plants (MOREIRA \& SIQUEIRA, 2006).

Formation and development of AMF morphological structures possibly depends on the plant and fungal species involved and on environmental conditions (ZHAO et al., 2016). Therefore, new research on the occurrence of these morphological structures grown in plant species associated with AMF must be performed. Given the importance of the topic, the present study aimed to assess the morphological pattern of arbuscular mycorrhizal fungi (AMF) colonization and the soil microbiological activity underlying acerola growth in family farming areas.

\section{MATERIALS AND METHODS}

The study area belongs to the municipality of Maranguape - Ceará (CE) and is located at the following geographical coordinates: $3^{\circ} 53^{\prime} 27^{\prime \prime}$ South and $34^{\circ} 41^{\prime} 08^{\prime \prime}$ West. It has a tropical wet-dry climate (Aw), according to the Köppen climate classification, and the collection period spanned from April to June 2014, with $368 \mathrm{~mm}$ rainfall and $30^{\circ} \mathrm{C}$ average temperature during the sampling season (FUNCEME, 2017). Four family farming areas planted with acerola were selected at the study site. Those areas were designated according to plant age as A1-3, A2-3, and A3-3 (3-yearold) and A4-2 (2-year-old), at collection time. The cultural treatments applied in the orchards consisted of soil supplementation with dry cow dung and mineral fertilization using sand. Furthermore, spontaneous vegetation was retained on the soil surface after hoeing and cutting, to maintain soil cover, thereby increasing soil moisture and reducing the erosion processes.

Samples were randomly collected at 20 sites in each area, at $0-20 \mathrm{~cm}$ depth, using stainless steel hoes and shovels to avoid contaminating the material after collecting each sample. Soil and root samples were packed in sealed bags and labeled according to the name of each study area. The samples were transported to the Soil Microbiology Lab, Department of Soil Sciences, Universidade Federal do Ceará (UFC), and subsequently sieved through a $2 \mathrm{~mm}$ mesh for the physical, chemical, and microbiological analysis procedures.

A composite sample of the mixture of soils from the 20 sampling points of each area was sent to the UFC Soil and Water Analysis Laboratory for physical and chemical characterization, according to the methods described by EMBRAPA (1997) (Table 1). However, the material for microbiological analysis (arbuscular mycorrhizal colonization, soil basal respiration, and spore density) was stored under refrigeration $\left(4^{\circ} \mathrm{C}\right)$ at the UFC Soil Microbiology Laboratory, until the analyses were performed.

Arbuscular mycorrhizal colonization (AMC) was assessed according to a method adapted from KOSKE \& GEMMA (1989). For each sample collected, 10 root fragments were arranged in parallel on microscope slides and observed at 400x magnification under an optical microscope. The percentage of root colonization by AMF was quantified using the method described 
Table 1 - Physical and chemical attributes of the topsoil layer $(0-20 \mathrm{~cm})$ collected from four areas of the municipality of Maranguape-CE.

\begin{tabular}{|c|c|c|c|c|}
\hline & A $1-3$ & A $2-3$ & A3-3 & A4-2 \\
\hline Textural classification & Sandy loam & Sandy loam & Sandy loam & Sandy-clayey loam \\
\hline pH (water) & 7.7 & 5.6 & 6.1 & 5.9 \\
\hline $\mathrm{EC}\left(\mathrm{dS} \mathrm{m}^{-1}\right)$ & 0.56 & 0.31 & 0.45 & 0.33 \\
\hline $\mathrm{Ca}^{2+}+\mathrm{Mg}^{2+}\left(\mathrm{cmol}_{\mathrm{c}} \mathrm{kg}^{-1}\right)$ & 6.70 & 2.60 & 3.60 & 3.80 \\
\hline $\mathrm{Na}^{+}\left(\mathrm{cmol}_{\mathrm{c}} \mathrm{kg}^{-1}\right)$ & 0.71 & 0.50 & 0.19 & 0.40 \\
\hline $\mathrm{K}^{+}\left(\mathrm{cmol}_{\mathrm{c}} \mathrm{kg}^{-1}\right)$ & 0.35 & 0.20 & 0.19 & 0.28 \\
\hline $\mathrm{H}^{+}+\mathrm{Al}^{3+}\left(\mathrm{cmol}_{\mathrm{c}} \mathrm{kg}^{-1}\right)$ & 0.83 & 3.30 & 2.64 & 1.82 \\
\hline$V(\%)$ & 91.0 & 50.0 & 62.0 & 71.0 \\
\hline $\mathrm{N}\left(\mathrm{g} \mathrm{kg}^{-1}\right)$ & 0.64 & 0.40 & 0.45 & 0.74 \\
\hline $\mathrm{OM}\left(\mathrm{g} \mathrm{kg}^{-1}\right)$ & 10.34 & 6.83 & 8.28 & 12.0 \\
\hline $\mathrm{P}\left(\mathrm{mg} \mathrm{kg}^{-1}\right)$ & 81.0 & 40.0 & 44.0 & 24.0 \\
\hline
\end{tabular}

EC: electric conductivity; OM: organic matter; A1-3; A2-3; A4-3 (3-year-old area); A4-2 (2-year-old area).

by MCGONIGLE et al. (1990) under an optical microscope at 400x magnification. The segments with vesicles, arbuscules, or typical hyphae, sometimes attached to spores, were considered colonized, and results were expressed as the percentage of root colonization. Based on the identification of AMF structures observed in the roots after the root staining procedure, the morphological pattern mycorrhization was classified as "Arum", "Paris" or "intermediate", according to DICKSON (2004).

The soil basal respiration (SBR) was assessed by quantifying the carbon dioxide $\left(\mathrm{CO}_{2}\right)$ released in the microbial respiration process from $50 \mathrm{~g}$ of soil packed in an airtight glass container, according to the method described by MENDONÇA \& MATOS (2005). AMF spore density (DS) was estimated in $100 \mathrm{~g}$ soil subsamples of the samples collected at the 20 sampling sites in each orchard by wet sieving (GEDERMANN \& NICHOLSON, 1963).

The statistical software package Statistics (SPSS) version 20 was used to perform the descriptive analysis of the study parameters. The following statistics were calculated: minimum, mean, maximum, and standard deviation. Data dispersion around the mean was calculated using the coefficient of variation (CV) and classified according to WILDING \& DREES (1983) as follows: low for $\mathrm{CV} \leq 15 \%$; moderate for $15 \%<\mathrm{CV} \leq 35 \%$; and high for $\mathrm{CV}>35 \%$. To test the hypothesis of normal distribution, the Shapiro-Wilk test was performed at $5 \%$ probability. The study parameters SBR, DS, and AMC of each area were plotted in box plots showing the descriptive statistics data and the presence or absence of outliers.

\section{RESULTS AND DISCUSSION}

The AMF morphological pattern as evaluated based on root colonization showed the predominance of Paris-type morphological structures (Figure 1) in acerola roots, in addition to the presence of vesicles and intracellular hyphae (Figure 1). Despite the lack of studies on AMF morphological patterns in the acerola crop, results from the present study indicated that this plant species favors Paristype morphologies. However, further studies will be necessary to elucidate the interaction between the symbionts because research on AMF morphological patterns in acerola crops is nonexistent. Morphological pattern of colonization depends on the plant-AMF combination, according to FEDDERMANN et al. (2010). The same authors reported that the plant and AMF genera are not necessarily compatible regarding the morphological pattern of colonization; although, different plant species tend to favor specific colonization morphologies. Furthermore, GUCWAPRZEPIÓRA et al. (2016) stated that; although, the plant species plays a key role in determining the morphological pattern of AMF root colonization, the type of pattern will depend on the AMF species and on the environmental conditions.

The Paris morphological pattern is characterized by the presence of intracellular hyphae and few arbuscules, which are often absent. Thus, the failure to identify arbuscules, as occurred in the presence study, has already been reported in previous studies (SMITH et al., 2009), particularly when the Paris morphology is prevalent. However, this absence does not necessarily preclude the main 


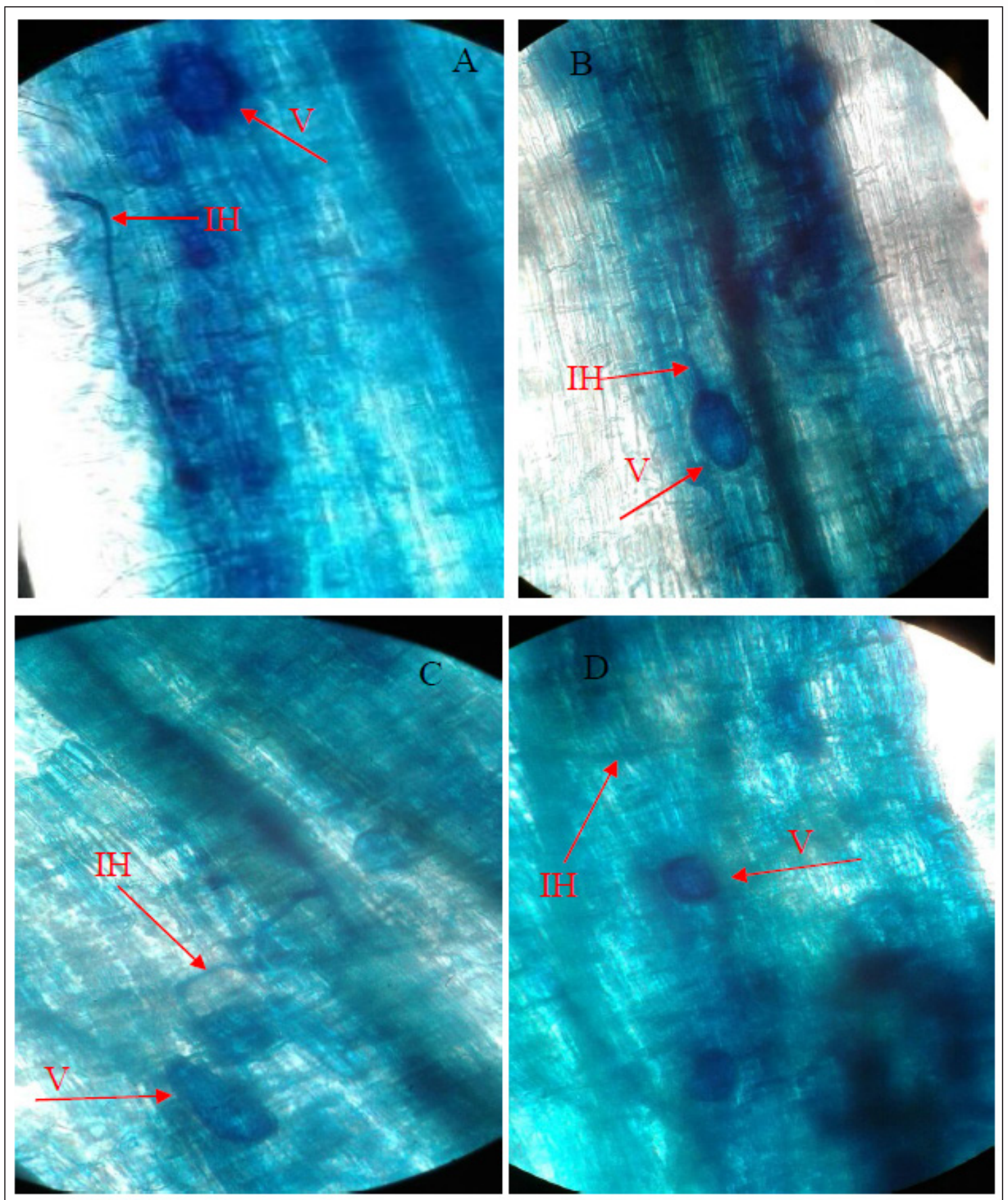

Figure 1 - Photomicrographs of the roots of acerola plants collected in the areas A1-3 (A), A2-3 (B), A3-3 (C), and A4-2 (D) after root staining. V: vesicle; IH: intraradical hyphae.

function of AMF in plant growth, which is the absorption of $\mathrm{P}, \mathrm{Cu}$, and $\mathrm{Zn}$, poorly mobile nutrients in soil. SMITH \& SMITH (2011a) reported that intracellular hyphae, arbuscules, and structures with intermediate morphology are involved in the transfer of nutrients to the host plant, not arbuscules alone. Therefore, the presence of the Paris morphological pattern in acerola roots is a positive factor for nutrient absorption in the crop, enhancing plant growth, which was also noted in other plant

Ciência Rural, v.47, n.12, 2017. 
species in a study conducted by BREARLEY et al. (2016). Similar findings were also reported by HARIKUMAR et al. (2015) in plants with the Paris morphological pattern with satisfactory growth.

The acerola AMC and DS data failed to follow a normal distribution, according to the Shapiro-Wilk Test $(P \leq 0.05)$; although, the SBR data tended toward a normal distribution.

The box plots (Figure 2) showed the parameters assessed in the four areas analyzed in the municipality of Maranguape - CE. Data dispersion around the mean, expressed as coefficient of variation $(\mathrm{CV})$, was low $(\mathrm{CV} \leq 15 \%)$ for the $\mathrm{AMC}$ and SBR variables, excluding the area $\mathrm{A} 2-3$ for the latter. DS showed a moderate CV $(15 \%<\mathrm{CV} \leq 35 \%)$ in all areas except A3-3.

The AMC of acerola ranged from $30.85 \%$ in area $\mathrm{A} 1-3$ to $52.17 \%$ in area $\mathrm{A} 4-2$ (Figure 2A). The above values were affected by the $\mathrm{P}$ contents reported in each area, which were 81 and $24 \mathrm{mg} \mathrm{kg}^{-1}$, respectively (Table 1), decreasing the percentage of colonization in area A1-3 and

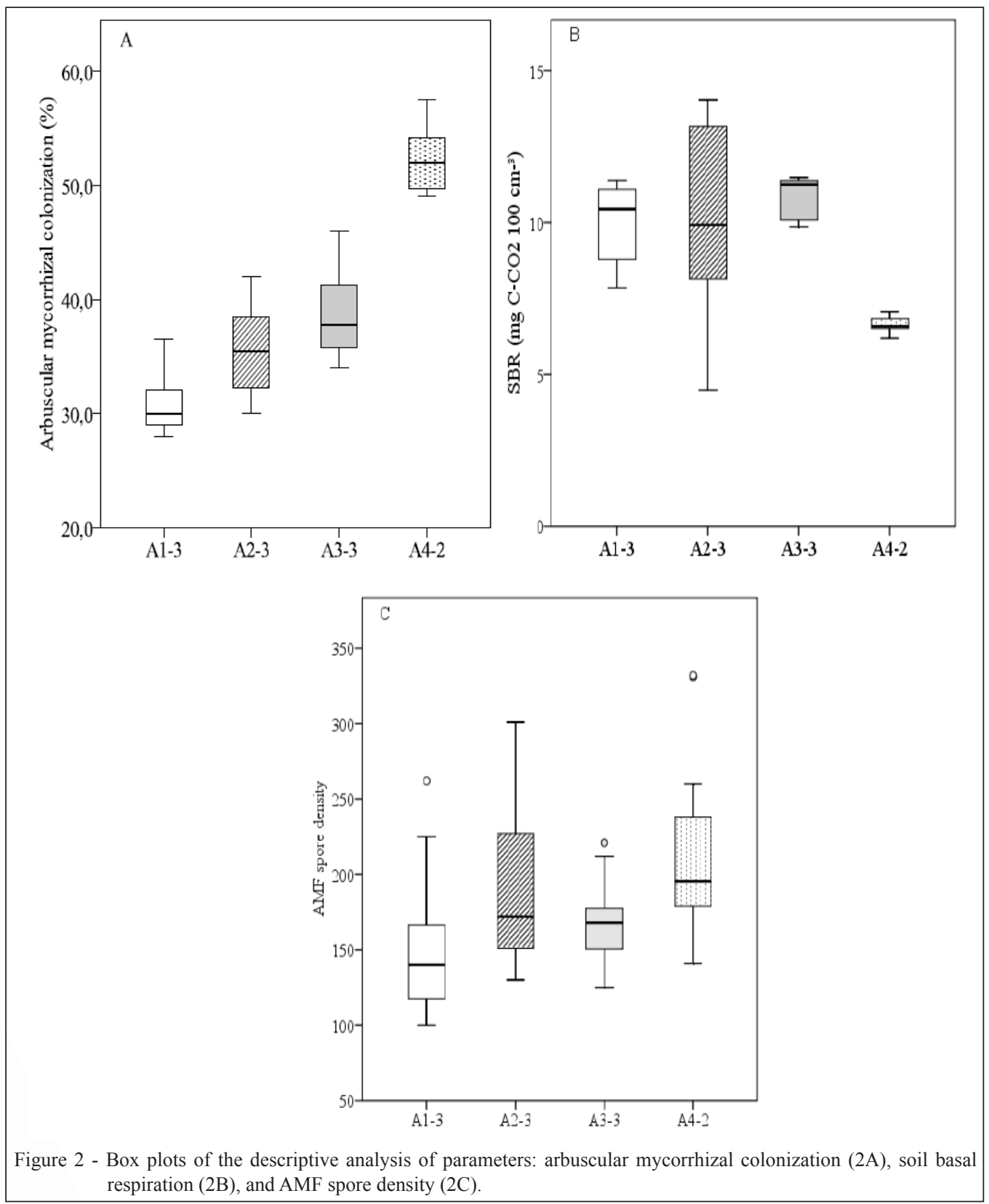

Ciência Rural, v.47, n.12, 2017. 
markedly increasing the colonization in area A4-2 because AMC may be adversely affected by soil $\mathrm{P}$ concentrations. High soil $\mathrm{P}$ content directly decreases the mycorrhizal colonization of several plant species, including acerola, according to YANG et al. (2016), DANTAS et al. (2015), and TAFFOUO et al. (2014). SMITH \& SMITH (2011b) reported that plants in good nutritional conditions trigger mechanisms to reduce AMF colonization toward reducing the energy cost of maintaining the fungus in the plant species.

SBR showed similar values in the four study areas, ranging from 6.64 to $10.81 \mathrm{mg}$ $\mathrm{C}-\mathrm{CO}_{2}$ day $^{-1} 100 \mathrm{~cm}^{-3}$ soil in areas A4-2 and A33 , respectively (Figure $2 \mathrm{~B}$ ). The lower SBR value observed in area A4-2 is related to the shorter crop growth season, because the soil microbial community is still presumably stabilizing from the stress of growing the acerola orchard. The traffic of machines and agricultural implements for soil plowing, harrowing, liming, or mineral fertilization, which are soil management practices that cause stress to the microbial population, is constant at the early growth season of perennial crops. PRAGANA et al. (2012) confirmed that the constant soil disturbance and absence of soil cover in conventional systems may reduce the soil microbial population and, therefore, microbial activity, requiring time to reestablish the balance reported prior to the stress on the organisms.

The DS of areas A1-3 and A4-2 was 150 and 211 spores per $100 \mathrm{~g}$ soil, respectively (Figure 2C). This marked variation in DS is mainly related to the climatic condition, soil, rainfall, and cultural treatments applied to the study areas. MELLONI et al. (2016) confirmed that DS usually shows a marked variation in cultivated soils because AMF spores are affected by several biotic and abiotic factors. LIMA et al. (2013) and JIMÉNEZ-LEYVA et al. (2017) confirmed that the DS in the rhizosphere is variable and is related to root distribution, morphology, and age, in addition to other factors including soil chemical characteristics (particularly $\mathrm{P}$ content), regional rainfall, and AMF species.

Thus, the decreased DS value observed in the A1-3 area was related to the high soil P content (Table 1), and the increased spore count was related to the decreased $\mathrm{P}$ content in the soil of area A4-2 (Table 1). These results are primarily related to the soil $\mathrm{P}$ concentrations because they may negatively or positively affect the signaling and growth of AMF in the soil and host plant.

\section{CONCLUSION}

The morphological pattern of the Paris type was prevalent in the acerola root system, clearly showing a crop affinity for that pattern. Although, the need for further studies to better understand the presence of that pattern in roots should be emphasized because research on acerola in this area of knowledge in soil biology is nonexistent.

The study season and acerola orchard management in the family farming areas decreased the basal soil respiration. The soil $\mathrm{P}$ content may have adversely affected AMF root colonization and spore density.

\section{REFERENCES}

BALOTA, E.L. et al. Resposta da acerola à inoculação de fungos micorrízicos arbusculares em solo com diferentes níveis de fósforo. Bragantia, v.70, n.1, p.166-175, 2011. Available from: <http:// www.scielo.br/pdf/brag/v70n1/v70n1a23.pdf > . Accessed: July 03, 2016. doi: 10.1590/S0006-87052011000100023.

BAUM, C. et al. Increasing the productivity and product quality of vegetable crops using arbuscular mycorrhizal fungi: a review. Scientia Horticulturae, v.187, p.131-141, 2015. Available from: <http://www.sciencedirect.com/science/article/ pii/S0304423815001211>. Accessed: Mar. 14, 2017. doi: 10.1016/j.scienta.2015.03.002.

BREARLEY, F.Q. Arbuscular mycorrhizal community structure on co-existing tropical legume trees in French Guiana. Plant and Soil, v.403, n.1, p.253-265, 2016. Available from: <https://link. springer.com/article/10.1007/s11104-016-2818-0>. Accessed: June 08, 2017. doi: 10.1007/s11104-016-2818-0.

DANTAS, B.L. et al. Diversity of arbuscular mycorrhizal fungi in na orchard of semi-arid land of Ceará, Brazil. Ciência Rural, v.45, n.8, p.1480-1486, 2015. Available from: <http://189.126.110.61/ crural/article/view/26404/27474>. Accessed: Mar. 20, 2017. doi: $10.1590 / 0103-8478 \mathrm{cr} 20130097$.

DICKSON, S. The Arum-Paris continuum of mycorrhizal symbioses. New Phytologist, v.163, n.1, p.187-200, 2004. Available from: <http://onlinelibrary-wiley-com.ez11.periodicos. capes.gov.br/doi/10.1111/j.1469-8137.2004.01095.x/epdf>. Accessed: May 28, 2016. doi: 10.1111/j.1469-8137.2004.01095.x.

EMPRESA BRASILEIRA DE PESQUISA AGROPECUÁRIA (EMBRAPA). Centro Nacional de Pesquisa de Solos. Manual de métodos de análise de solo. 2.ed. Rio de Janeiro, 1997. 212p.

FEDDERMANN, N. et al. Functional diversity in arbuscular mycorrhiza - the role of gene expression, phosphorous nutrition and symbiotic efficiency. Fungal Ecology, v.3, p.1-8, 2010. Available from: <http://www.elsevier.com/locate/funeco $>$. Accessed: Mar. 17, 2017. doi: 10.1016/j.funeco.2009.07.003.

FERREIRA, G.M. dos R. et al. Arbuscular mycorrhizal fungi in seedling development of olive (Olea europaea L.) in the south of Minas Gerais, Brazil. Revista Brasileira de Ciência do Solo, v.39, n.2, p.361-366, 2015. Available from: <http://www.redalyc. 
org/articulo.oa?id=180239737004>. Accessed: June 08, 2016. doi: $10.1590 / 01000683 \mathrm{rbcs} 20140082$

FIGUEIREDO NETO, A. et al. Determinação de vitamina C e avaliação físico-química em três variedades de acerola cultivadas em Petrolina-PE. Nucleus, v.11, n.1, p.83-92, 2014. Available from: $<$ http://nucleus.feituverava.com.br/index.php/nucleus/article/ view/987>. Accessed: June 05, 2016. doi: 10.3738/1982.2278.987.

FUNCEME (FUNDAÇÃO CEARENSE DE METEOROLOGIA E RECURSOS HÍDRICOS). Fortaleza, 20 jun. 2017. Available from: <http://www.funceme.br>. Accessed: June 20, 2017.

GERDEMANN, J.W.; NICHOLSON, T.H. Spores of mycorrhizal Endogene species extracted from soil by wet sieving and decanting. Transactions of the British Mycological Society, v.46, n.2, p.235-244, 1963. Available from: <http://www.sciencedirect. com/science/article/pii/S0007153663800790>. Accessed: Apr. 15, 2016. doi: 10.1016/S0007-1536(63)80079-0.

GUCWA-PRZEPIÓRA, E. et al. AM and DSE colonization of invasive plants in urban habitat: a study of Upper Silesia (southern Poland). Journal of Plant Research, v.129, n.4, p.603-614, 2016. Available from: $<$ http://link-springer-com.ez11.periodicos. capes.gov.br/content/pdf/10.1007\%2Fs10265-016-0802-7.pdf $>$. Accessed: Mar. 18, 2017. doi: 10.1007/s10265-016-0802-7.

HARIKUMAR, V.S. et al. Arbuscular mycorrhizal fungi colonizing the plant communities in Eritrea, Northeast Africa. Applied Ecology and Environmental Research, v.13, n.1, p.193-203, 2015. Available from: <https:/www.researchgate. net/publication/265209442_Arbuscular_mycorrhizal_ fungi colonizing the plant communities in Eritrea northeast_Africa $>$. Accessed: June 19, 2017. doi: $10.1566 \overline{6}$ aeer/1301 193203

JIMÉNEZ-LEYVA, J.A. et al. Phenological and ecophysiological responses of Capsicum annuum var. glabriusculum to native arbuscular mycorrhizal fungi and phosphorus availability. Environmental and Experimental Botany, v.138, p.193-202, 2017. Available from: <http://www.sciencedirect.com/science/ article/pii/S009884721730076X $>$. Accessed: Mar. 25, 2017. doi: 10.1016/j.envexpbot.2017.03.008.

KOSKE R.E.; GEMMA, J.N. A modified procedure for staining roots to detect VA mycorrhizas. Mycological Research, v.92, n.4, p.486-505, 1989. Available from: <http://www.sciencedirect. com/science/article/pii/S0953756289801959>. Accessed: Apr. 10 2016. doi: 10.1016/S0953-7562(89)80195-9.

LIMA, F. de S. et al. Ocorrência e atividade de fungos micorrízicos arbusculares em plantios de eucalipto (Eucalyptus sp.) no litoral norte da Bahia, Brasil. Revista Árvore, v.37, n.2, p.245255, 2013. Available from: <http://www.redalyc.org/articulo. oa? id=48827959006>. Accessed: May 30, 2016.

MCGONIGLE, T.P. et al. A new method which gives an objective measure of colonization of roots by vesiculararbuscular mycorrhizal fungi. New Phytologist, v.115, n.3, p.495-501, 1990. Available from: <http://onlinelibrary.wiley.com/ doi/10.1111/j.1469-8137.1990.tb00476.x/epdf>. Accessed: Apr. 11, 2016. doi: 10.1111/j.1469-8137.1990.tb00476.x.

MELLONI, R. et al. Propágulos e formação de micorriza em taludes de rodovia, no sul de Minas Gerais, Brasil. Revista Brasileira de Ciências Agrárias, v.11, n.1, p.26-32, 2016. Available from:
$<$ http://www.redalyc.org/html/1190/119045655005/>. Accessed: Mar. 11, 2017. doi: 10.5039/agraria.v11i1a5356.

MENDONÇA, E. de Sá; MATOS, E da S. Matéria orgânica do solo: métodos de análises. Viçosa: editora UFV 2005. V.1, 107p.

MOREIRA, F.M.S.; SIQUEIRA, J O. Microbiologia e bioquímica do solo. 2.ed. Lavras: Federal University of Lavras (Universidade Federal de Lavras - UFLA), 2006. 729p.

PRAGANA, R.B. et al. Atributos biológicos e dinâmica da matéria orgânica em Latossolos Amarelos na região do Cerrado Piauiense sob sistema plantio direto. Revista Brasileira Ciência do Solo, v.36, n.3, p.851-858, 2012. Available from: <http:/www.scielo.br/ pdf/rbcs/v36n3/15.pdf $>$. Accessed: Apr. 26, 2016. doi: 10.1590/ S0100-06832012000300015.

ROSA, D.M. et al. Substâncias húmicas do solo cultivado com plantas de cobertura em rotação com milho e soja. Revista Ciência Agronômica, v.48, n.2, p.221-230, 2017. Available from: <http:// www.scielo.br/pdf/rca/v48n2/1806-6690-rca-48-02-0221.pdf $>$. Accessed: Mar. 16, 2017. doi: 10.5935/1806-6690.20170026.

SMITH, F.A. et al. More than a carbon economy: nutrient trade and ecological sustainability in facultative arbuscular mycorrhizal symbioses. New Phytologist, v.182, n.2, p.347-358, 2009. Available from: <http://onlinelibrary.wiley.com/doi/10.1111/ j.1469-8137.2008.02753.x/epdf>. Accessed: Apr. 05, 2016. doi: 10.1111/j.1469-8137.2008.02753.x.

SMITH, F.A.; SMITH, S.E. What is the significance of the arbuscular mycorrhizal colonisation of many economically important crop plants? Plant and Soil, v.348, n.1, p.63-79, 2011b. Available from: $<$ http://link.springer.com/article/10.1007/s11104-011-0865-0>. Accessed: Apr. 06, 2016. doi: 10.1007/s11104-011-0865-0.

SMITH, S.E.; SMITH, F.A. Roles of arbuscular mycorrhizas in plant nutrition and growth: new paradigms from cellular to ecosystem scales. Annual Review of Plant Biology, v.62, p.227-250, 2011a. Available from: <https://www.ncbi.nlm.nih. gov/pubmed/21391813>. Accessed: Apr. 06, 2016. doi: 10.1146/ annurev-arplant-042110-103846.

TAFFOUO, V.D. et al. Influence of phosphorus application and arbuscular mycorrhizal inoculation on growth, foliar nitrogen mobilization, and phosphorus partitioning in cowpea plants. Mycorrhiza, v.24, p.361-368, 2014. Available from: <https:// www.ncbi.nlm.nih.gov/pubmed/24322505>. Accessed: June 18, 2017. doi: 10.1007/s00572-013-0544-5.

WILDING, L.P.; DREES, L.R. Spatial variability and pedology. In: WILDING, L.P. et al. (Eds.). Pedogenesis and soil taxonomy: concepts and interactions. New York: Elsevier, 1983. p.83-116.

YANG, G. et al. Arbuscular mycorrhizal fungi affect plant community structure under various nutrient conditions and stabilize the community productivity. Oikos, v.125, n.4, p.576-585, 2016. Available from: <http://onlinelibrary.wiley.com/doi/10.1111/ oik.02351/epdf>. Accessed: Mar. 28, 2017. doi: 10.1111/oik.02351.

ZHAO, X. et al. Arbuscular mycorrhizal and dark septate fungal associations in riparian plants of the Three Gorges Reservoir Region, Southwest China. Aquatic Botany, v.133, p.28-37, 2016. Available from: $<$ http://www.sciencedirect.com/science/article/pii/ S0304377016300444>. Accessed: June 08, 2017. doi: 10.1016/j. aquabot.2016.05.003. 